\title{
Vacuum Infusion with Daminozide for Retarding Potted Chrysanthemum Height
}

\author{
Kenneth C. Sanderson ${ }^{1}$, Durward A. Smith ${ }^{2}$, and John A. McGuire ${ }^{3}$ \\ Department of Horticulture, Alabama Agricultural Experiment Station, Auburn \\ University, AL 36849-5408
}

Additional index words. growth regulators, Dendranthema $\times$ grandiflorum, B-Nine

Improved efficiency of growth retardant application could reduce cost and minimize pollution and applicator health risks. Application methods such as encapsulated formulations (Read et al., 1974), impregnated propagation blocks (Witte and Tjia, 1976), incorporated granules (Wilfret et al., 1978), cutting soaks (Von Hentig, 1979), tablets, capsules, and injected gels (Sanderson et al., 1988) have been suggested for improving the efficiency of plant growth retardants. The poor performance of some retardants due to environmental conditions, such as temperature and other factors (Crater, 1992), and absorption by growth medium (Barrett, 1982) could possibly be overcome by more efficient application. Growth retardants are usually applied as either sprays or drenches on potted chrysanthemum [Dendranthema $\times$ grandiflorum (Ramat.) Kitamura], but sprays are generally used because of the low cost and general effectiveness of the chemical most commonly used: butanedionic acid mono(2,2-dimethyl-hydrazide) (daminozide). Daminozide sprays can be ineffective on tall-growing chrysanthemum cultivars and at certain times of the year (Yoder, 1983). Dipping or total immersion of rooted or unrooted cuttings into daminozide at 1000 $\mathrm{mg} \cdot$ liter $^{-1}$ for $10 \mathrm{sec}$ followed by 24-h refrigerated storage before transplanting or propagation has been suggested when shoot growth is difficult to control (Yoder, 1983).

Received for publication 16 July 1993. Accepted for publication 5 Nov. 1993. Alabama Agricultural Experiment Station journal series no. 11-933560, Appreciation is expressed to Yoder Brothers, Barberton, Ohio, for the chrysanthemum cuttings and Uniroyal, Bethany, Conn., for the daminozide used in this study. The cost of publishing this paper was defrayed in part by the payment of page charges. Under postal regulations, this paper therefore must be hereby marked advertisement solely to indicate this fact.

'Professor of Horticulture.

${ }^{2}$ Former Associate Professor of Horticulture. Current address: Dept. of Horticulture, Univ. of Nebraska, Lincoln.

${ }^{3}$ Head, Research Data Analysis.
Vacuum infusion has been used in the food industry to preserve the quality of stored apples (Malus domestica Borkh.) (Lidster et al., 1986) and carrots (Daucus carota L.) (Bruemmer, 1987). The technology also may be useful for intimately contacting plant tissue with growth regulators. In the present investigation, we examined the effect of vacuum infusion of daminozide on chrysanthemum cuttings for controlling plant height and width.

'Engarde' chrysanthemums a cultivar with long internodes whose height is not effectively controlled by conventional daminozide sprays. Unrooted cuttings either were totally immersed in daminozide at $1000 \mathrm{mg} \cdot$ liter $^{-1}$ for $10 \mathrm{sec}$ or received vacuum-infusion treatments (VIT) of daminozide at $0,125,250$, or $500 \mathrm{mg}$.liter ${ }^{-1}$. For VIT, six to ten cuttings were submerged in trays containing the daminozide solutions. Trays were placed in a vacuum chamber for 15 $\mathrm{sec}$ at $42.5 \mathrm{kPa}$. Time for VIT had been determined preliminarily by using a binocular microscope to examine cuttings for damage following various treatment times (data not shown). Following VIT, the cuttings were removed from the chamber and allowed to remain in solution until bubbling ceased $(\approx 3$ min). All cuttings were then removed from the solution, drained, air-dried, placed in plastic bags, and refrigerated overnight at $7 \mathrm{C}$.

Four stem cuttings of each treatment were then propagated in 1.5-liter pots containing a growing medium of 1 soil : 1 sphagnum peat: 1 perlite (by volume). During propagation, cuttings were misted with water for 10 out of $90 \mathrm{sec}$ from 9:00 AM to 4:30 PM. After rooting, standard cultural practices for commercial potted chrysanthemums were used (Crater, 1992; Yoder, 1983). The pots were arranged in the greenhouse in a randomized block design with six replications of the six treatments. A pot with four plants was the experimental unit. When one-half of the flowers in each pot were open, plant height was measured from the medium surface and plant area (canopy measured in two directions and multiplied) was determined.

Immersion of cuttings in daminozide at $1000 \mathrm{mg} \cdot$ liter $^{-1}$ for $10 \mathrm{sec}$ and $250 \mathrm{mg} \cdot$ liter $^{-1}$ via
VIT retarded plant height equally (Table 1). Regression analyses of VIT concentration data for linear, quadratic, and cubic contrasts were nonsignificant. The results suggest VIT has potential as a method to apply daminozide to chrysanthemums. Lower concentrations of retardant were effective when VIT rather than immersion was used. Plant area (range 629 to $799 \mathrm{~cm}^{2}$ ) was unaffected by any of the treatments. Overnight storage of cuttings before propagation may not be necessary when cuttings are vacuum-infused with a retardant. This feature and tests with other retardants merit further investigation.

\section{Literature Cited}

Barrett, J.E. 1982. Chrysanthemum height control by ancymidol, PP333 and EL-500 dependent on medium composition. HortScience 17:896-897.

Bruemmer, J.H. 1987. Stability of prepared carrot sticks in storage, Proc. Fla. State Hort. Soc. 100:36-38.

Crater, G.D. 1992. Pot mums, p. 251-287. In: R.A. Larson (ed,). Introduction to floriculture. Academic, New York.

Lidster, P.D., A.J. Dick, A. DeMarco, and K.B. McRae. 1986. Application of flavonoid glycosides and phenolic acids to suppress firmness loss in apples. J. Amer. Soc. Hort. Sci. 111:892896.

Read, P.E., W.L. Herman, and D.A. Heng. 1974. Slow-release chlormequat-A new concept in plant growth regulators. HortScience 9:55-57.

Sanderson, K.C., W.C. Martin, Jr., and J. McGuire 1988. Comparison of paclobutrazol tablets, drenches, gels, capsules and sprays on chrysanthemum growth. HortScience 23:1008-1009.

Von Hentig, W.D. 1979. Early treatment of ornamental plants with retarding substances. Acta Hort. 91:353.

Wilfret, G.J., B.K. Harbaugh, and T.A. Nell. 1978 Height control of Pixie poinsettia with a granular formulation of ancymidol. HortScience 13:701-702.

Witte, W.T. and B. Tjia. 1976. Effect of ancymidol impregnated propagation blocks on height of poinsettia. Proc. Fla. State Hort. Soc. 81:283284.

Yoder, G.R. 1983. Pot mum culture. Yoder products for 1983-84 something to grown on. Yoder Brothers, Barberton, Ohio. p. 14-18.

Table 1. Height of 'Engarde' potted chrysanthemums grown from cuttings dipped in or vacuuminfused with daminozide.

\begin{tabular}{lcl}
\hline \multicolumn{2}{c}{ Daminozide application } & \\
\hline Method & Concn (mg-liter $\left.{ }^{-1}\right)$ & $\mathrm{Ht}(\mathrm{cm})$ \\
\hline Control $^{\mathrm{z}}$ & 0 & $25.7 \mathrm{a}^{y}$ \\
Vacuum-infused $^{\text {Tap water }}$ & 0 & \\
& 125 & $24.5 \mathrm{ab}$ \\
& 250 & $25.2 \mathrm{a}$ \\
& 500 & $22.8 \mathrm{bc}$ \\
Total immersion & 1000 & $24.7 \mathrm{ab}$ \\
\hline
\end{tabular}

${ }^{2}$ Plants not treated with water or daminozide.

'Mean separation by Duncan's multiple range test, $P$ $\leq 0.05$. 